\title{
Involuntary movement in infants during vitamin B12 treatment
}

\author{
Süt çocuklarında vitamin B12 tedavisi sirasinda gelişen istemsiz hareketler
}

\author{
Ayşe Tosun ${ }^{1}$, Yusuf Ziya Aral2, Emre Çeçen ${ }^{3}$, Ayvaz Aydoğdu 4 , Bilin Çetinkaya Çakmak ${ }^{4}$ \\ 1Department of Pediatric Neurology, Faculty of Medicine, Adnan Menderes University, Aydin, Turkey \\ ${ }^{2}$ Department of Pediatric Hematology, Faculty of Medicine, Adnan Menderes University, Aydin, Turkey \\ ${ }^{3}$ Department of Pediatric Oncology, Faculty of Medicine, Adnan Menderes University, Aydin, Turkey \\ ${ }^{4}$ Department of Pediatrics, Faculty of Medicine, Adnan Menderes University, Aydin, Turkey
}

\begin{abstract}
Megaloblastic anemia is rare in infants and is generally due to vitamin B12 (cobalamin) deficiency in the mother. Neurologic symptoms of vitamin B12 deficiency include irritability, failure to thrive, hypotonia, and developmental regression/delay. Herein we present 2 infants with vitamin B12 that developed movement disorder $5 \mathrm{~d}$ after initiation of vitamin B12 treatment. Symptoms included tremor and myoclonus, involving in particular the face, tongue, and hands. Clinical findings in infants associated with vitamin B12 deficiency vary, and temporary involuntary movement can be observed during vitamin B12 therapy. (Turk J Hematol 2011; 28: 317-22)
\end{abstract}

Key words: Involuntary movement, vitamin B12 deficiency, infant

Received: June 11, 2010

Accepted: October 19, 2010

\section{Özet}

Süt çocuklarında megaloblastik anemi nadirdir ve genellikle annelerdeki vitamin B12 eksikliğinin bir sonucudur. Kobalamin eksikliğinin nörolojik semptomları huzursuzluk, büyüme geriliği, hipotoni ve nörogelişimsel becerilerde gerileme/gecikmeyi içerir. Bu makalede kobalamin tedavisinin 5. gününde özellikle dil, yüz, elleri içine alan tremor ve miyoklonus gibi istemsiz hareketler gelişen, kobalamin eksikliği olan, iki süt çocuğu sunuldu. Süt çocuklarında kobalamin eksikliği farklı klinik bulgularla karşımıza gelebilir ve tedavisi sırasında geçici istemsiz hareketler görülebilir. (Turk J Hematol 2011; 28: 317-22)

Anahtar kelimeler: İstemsiz hareketler, B12 vitamini eksikliği, süt çocuğu

Geliş tarihi: 11 Haziran 2010

Kabul tarihi: 19 Ekim 2010

Address for Correspondence: Assoc. Prof. Ayşe Tosun, Department of Pediatric Neurology, Faculty of Medicine, Adnan Menderes University, 09100 Aydın, Turkey Phone: +90 25644412 56-1371 E-mail: aysetosun2000@yahoo.com

doi:10.5152/tjh.2011.18 


\section{Introduction}

Nutritional megaloblastic anemia is a rare disorder in infants and is generally due to vitamin B12 (cobalamin) deficiency in the mother. Vitamin B12 is an essential vitamin and must be obtained from animal-derived nutrients, such as meat, fish, eggs, milk, and meat. During pregnancy, vitamin B12 passes from the placenta to the fetus via active transport and is stored in the fetus' liver. In infants born with a sufficient quantity of stored vitamin B12, vitamin B12 deficiency is rare; however, in developing countries vitamin B12 deficiency is common in infants born to mothers with pernicious anemia, those on a strict vegetarian diet, and those that are malnourished [1-3].

Although clinical findings show that vitamin B12 deficiency can be tolerated by adults for many years due to their endogenous reserve, in infants it may produce symptoms 2-12 months following birth due to an inadequate hepatic reserve [1-6]. Patients with vitamin B12 deficiency present with hematological, neurological, and psychiatric symptoms, which are more commonly observed in adults. Nevertheless, severe neurological problems, in addition to anemia, may be observed in infants that are fed no animal-derived nutrients, but only breast milk $[1,6]$.

Vitamin B12 deficiency causes fatigue, restlessness, vomiting, difficulty swallowing solid food, and delay or regression of growth and development. Severe neurological findings, such as hypotonia, apathy, decreased eye contact, involuntary movement, seizure, lethargy, and coma, have been reported $[1,3,4,7,8]$. A delay in the diagnosis and treatment of vitamin B12 deficiency can lead to irreversible psychomotor retardation and neurological damage. Herein we present 2 male infants with severe vitamin B12 deficiency that presented with hematologic, neurologic, and typical cranial magnetic resonance imaging (MRI) findings, as well as involuntary movement during vitamin B12 therapy.

\section{Case 1}

A 6-month-old male that was fed only breast milk presented to our hospital with a chronic cough and dyspnea. He was born full term, weighing 3770 gram after an uncomplicated pregnancy and delivery.
He was able to control his head at age 2 months. His mother had been treated for iron deficiency anemia during the pregnancy.

The patient's weight was in the $50^{\text {th }}-75^{\text {th }}$ percentile, and height and head circumference were in the $25^{\text {th }}-50^{\text {th }}$ percentile. At presentation he was pale and anxious, and had respiratory distress and hepatomegaly. He did not establish eye contact, lacked head control, and was not able to sit without support. Muscle strength was low and reflexes were brisk. Complete blood count results were as follows: macrocytic anemia; hemoglobin (Hb) level: $4.9 \mathrm{~g} / \mathrm{dL}$; white blood cell (WBC) count: $2800 \mathrm{~mm}^{3}$; platelet (PLT) count: $95,000 \mathrm{~mm}^{3}$; mean corpuscular volume (MCV): $102 \mathrm{fL}$; red blood cell distribution width (RDW): 21.6\%. Peripheral blood smear showed anisocytosis, macrocytosis, poikilocytosis, single and double (few) sets of platelets, and hypersegmented neutrophils (few).

Routine urine analysis was normal. Serum immunoglobulin G (IgG) was $3.29 \mathrm{~g} / \mathrm{L}$ (normal: 7-16 g/L), IgA was $<0.24 \mathrm{~g} / \mathrm{L}$ (normal: $0.7-4 \mathrm{~g} / \mathrm{L}$ ), and IgM was $0.405 \mathrm{~g} / \mathrm{L}$ (normal: 0.4-2.3 g/L). Biochemical profile and thyroid function tests, and serum iron, ferritin, and folate levels were normal. Serum vitamin B12 was $56.51 \mathrm{pg} / \mathrm{mL}$ (normal: 197-866 pg/mL). Bone marrow examination was performed due to pancytopenia and megaloblastic changes were observed. Cranial MRI showed atrophy in the frontoparietal cortex and interhemispheric regions, with dilatation in the ventricles (Figure 1a and b). Plasma homocysteine and methylmalonic acid levels were not determined, as they are not routinely measured in our hospital. Additionally, the patient's mother has maintained a vegetarian diet. The mother's serum ferritin and vitamin B12 levels were low $(6 \mathrm{ng} / \mathrm{mL}$ and $150 \mathrm{pg} / \mathrm{mL}$, respectively); proteinuria was not observed.

The patient was diagnosed as nutritional megaloblastic anemia due to inadequate intake of vitamin B12, and parenteral vitamin B12 treatment (10 $\mu \mathrm{g} / \mathrm{d}$ for 2 days, then $100 \mu \mathrm{g} / \mathrm{d}$ for 2 days, followed by $1000 \mu \mathrm{g} / \mathrm{d}$ for 1 week) was started. Following administration of 1 unit of erythrocyte suspension for tachycardia and severe anemia. On the $5^{\text {th }} \mathrm{d}$ of treatment generalized tremors and myoclonus were observed in the patient's hands, feet, tongue, and lips; therefore, the patient underwent electroencephalogram (EEG) examination and the results were normal. 

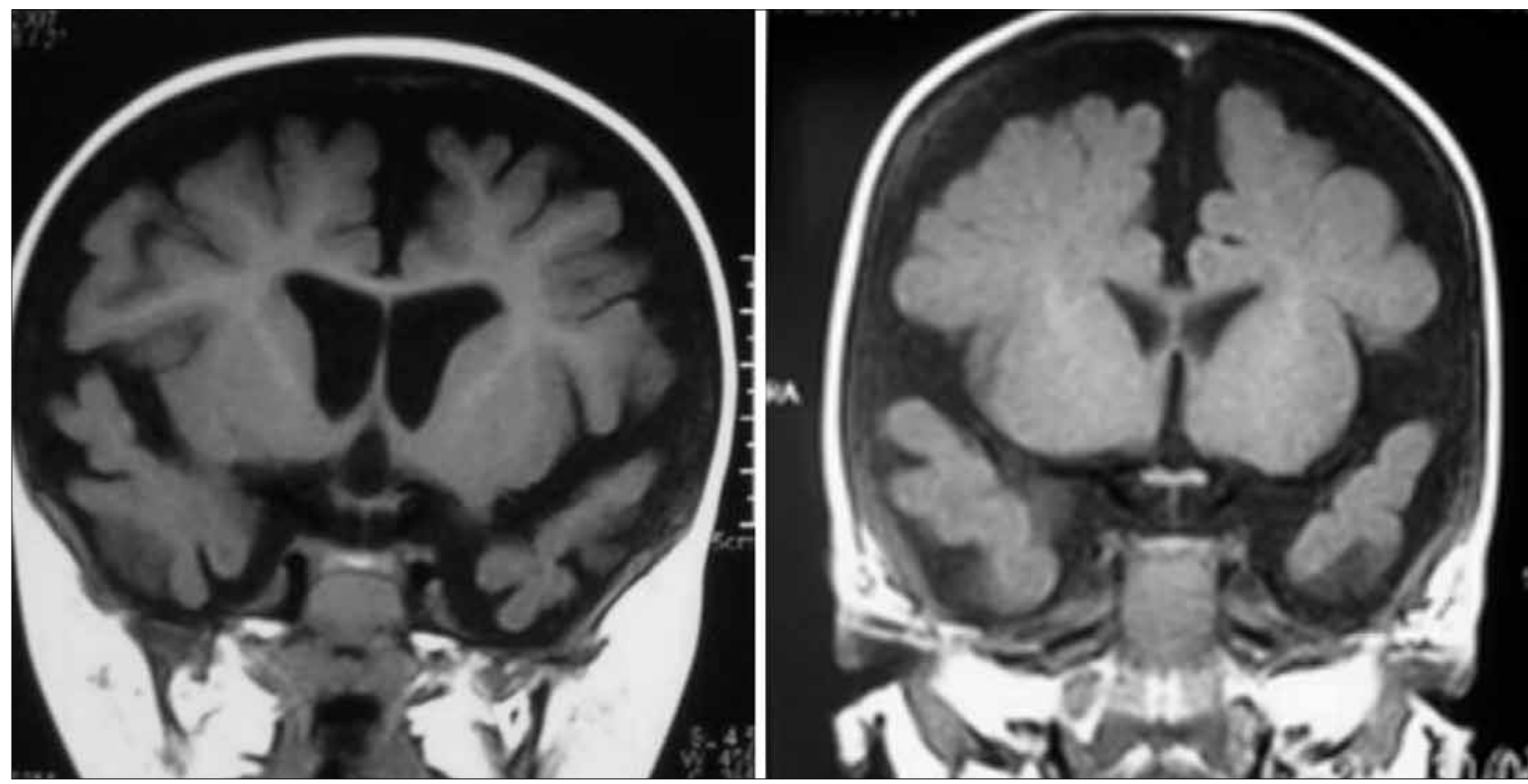

Figure 1. Coronal T1-Weighted Cranial MRI Shows Bilateral Atrophy in the Frontoparietal Region and Dilatation in the Ventricles

Oral piracetam therapy was initiated $(40 \mathrm{mg} / \mathrm{kg} /$ day) and on the $7^{\text {th }} \mathrm{d}$ of therapy, and myoclonus and tremor disappeared. Pirasetam treatment was interrupted after 3 weeks. One month after the therapy began the patient's anemia improved, he could control his head and sit without support, and was more interested in his environment. At 18 months of age his neurologic development, Ig levels, serum vitamin B12 level, and complete blood count were normal.

\section{Case 2}

A 13-month-old male presented to our hospital with fatigue, weakness, recurrent bronchiolitis, and megaloblastic anemia. He was born weighing 3300 $\mathrm{g}$ following an uneventful pregnancy. He was able to control his head at age 3 months. Upon presentation he was still primarily fed breast milk and was vomiting when fed animal-based nutrients, such as eggs, milk, and meat. Family history was unremarkable. The patient's weight and head circumference were in the $10^{\text {th }}-25^{\text {th }}$ percentile and his height was in the $25^{\text {th }}-50^{\text {th }}$ percentile.

At presentation he was pale and anxious. Cardiac examination showed a $1 / 6$ systolic murmur in the mesocardial area. Muscle strength and tonus were normal, and deep tendon reflexes were normoactive. He could not sit without support. There was developmental delay, including rough motor (sitting, crawling, walking), thin motor (grasping objects), speech (no significant words), and social (apathetic, doesn't smile, poor eye contact). Complete blood count results were as follows: $\mathrm{Hb}$ level: $8.3 \mathrm{~g} / \mathrm{dL}$; WBC count: 23,500 $\mathrm{mm}^{3}$; PLT count: 146,000 mm33 MCV: 104 fL; RDW: 23.5\%. Peripheral blood smear showed hypochromia, anisocytosis, and macrocytosis. Routine urinalysis was normal. Serum vitamin B12 was low (140 pg/mL) and other biochemical profiles (thyroid function tests, and serum electrolyte, iron, ferritin, and folate levels) were normal. Serum IgM was low $(0.3 \mathrm{~g} / \mathrm{L})$ (normal: 0.4-2.3 g/L) and the others immunoglobulin were normal. Plasma homocysteine and methylmalonic acid levels were not determined, as they are not routinely measured in our hospital. Cranial MRI showed atrophy in the frontoparietal region and dilatation in the ventricles (Figure 2). Although the complete blood count parameters in the mother and father were normal, their serum vitamin B12 levels were 150 and $188 \mathrm{pg} / \mathrm{mL}$, respectively. The parents did not have proteinuria. The patient's mother has maintained a vegetarian diet for many years. 


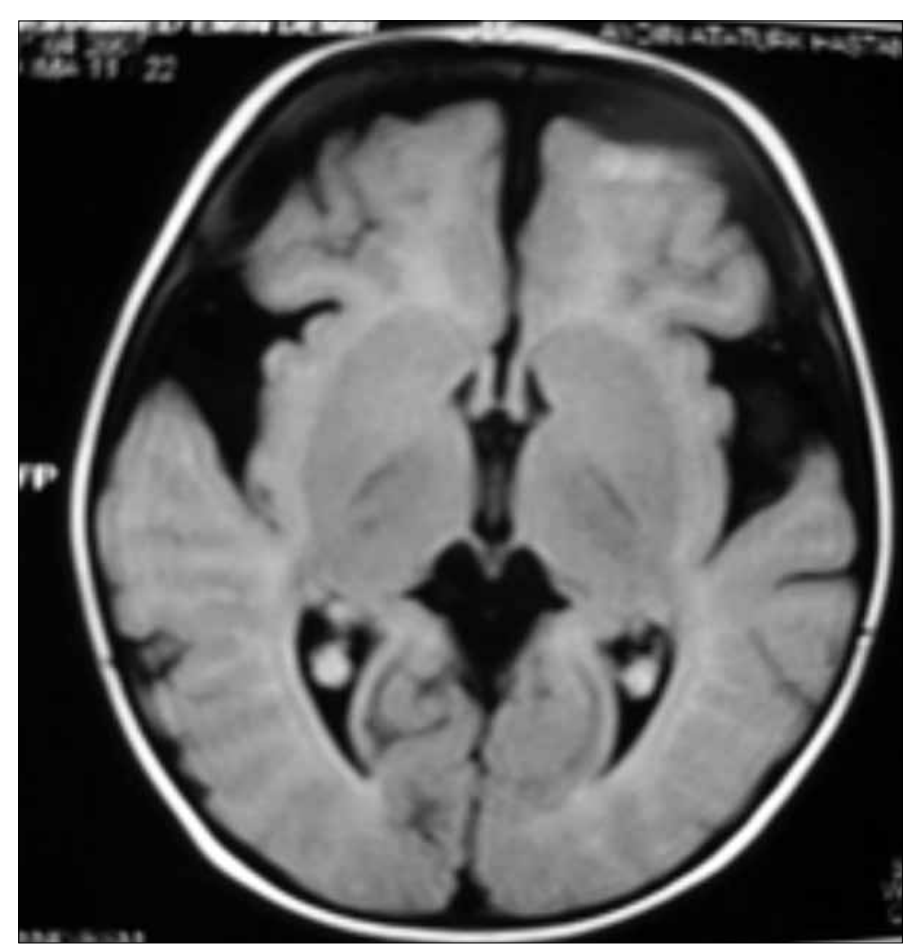

Figure 2. Axial T1-Weighted Cranial MRI Shows Severe Bilateral Cortical Frontoparietal Atrophy and Ventricular Dilatation

The patient was diagnosed as megaloblastic anemia due to inadequate B12 intake, and subcutaneous vitamin B12 treatment $(100 \mu \mathrm{g} / \mathrm{d}$ for 1 week and then $100 \mu \mathrm{g} / \mathrm{d}$ every other day for 2 weeks, then $100 \mu \mathrm{g} / \mathrm{d}$ twice a week for 1 week, followed by 100 $\mu \mathrm{g}$ once a week for 4 weeks) was started. On the 5th $\mathrm{d}$ of treatment tremors and myoclonus began in the patient's right wrist, and in both hands, arms, and legs. His EEG was normal. We thought that the involuntary movements were due to vitamin B12 therapy, and therefore added piracetam $(40 \mathrm{mg} / \mathrm{kg} /$ day) to the treatment regimen. During the first week of the new treatment regimen tremors and myoclonus disappeared by gradually decreasing and ended 6th day. Pirasetam treatment was interrupted after 3 weeks. At the 6-month follow-up the patient's neurologic examination results and serum vitamin B12 level were normal. Informed consents were obtained from the patients.

\section{Discussion}

Patients with vitamin B12 deficiency usually have clinical findings related to the central nervous system, such as developmental delay, microcephaly, hypotonia, lethargy, irritability, involuntary movement, and seizures, 2-12 months after birth.
Involuntary movements, such as tremor and myoclonus, can be the first clinical symptoms of vitamin B12 deficiency or can appear several days after the start of vitamin B12 therapy. The duration of movement disorder is $10-30 \mathrm{~d}$. The severity, nature, and timing of movement disorder are highly variable $[1,4,7]$.

Jadhav et al. [9] first described nutritional vitamin B12 deficiency in 6 Indian infants aged 6-12 months that presented with megaloblastic anemia, psychomotor regression, and hyper pigmentation of the skin. Grech et al. [10] were the first to describe temporary involuntary movements in a 3 -month-old patient with congenital transcobalamin deficiency on the $4^{\text {th }}$ day of parenteral vitamin B12 treatment. Chandra et al. [11] reported that coarse tremors that occurred initially in the hands and feet gradually became generalized in 6 of 51 megaloblastic anemia patients treated with vitamin B12. Ozer et al. [12] reported 2 vitamin B12deficient Turkish infants that were fed only breast milk and presented with fatigue, anemia, and developmental delay. Involuntary movements of the tongue, face, hands, and legs, such as tremor and myoclonus, appeared in both patients a few days after treatment with intramuscular vitamin B12. Their neurologic symptoms improved after initiating clonazepam treatment. Özdemir et al. [13] and Avcl et al. [14] reported involuntary movements, including tremor and irregular shaking movements, during vitamin B12 treatment. The movements disappeared following clonazepam/piracetam/biperiden hydrochloride therapy.

In accordance with the literature, the 2 presented cases were breastfed. In case 1 rough motor development regression, such as head control, and in case 2 developmental delay, such as sitting, crawling, grasping, and speaking, were observed. Although the 2 cases received different doses of vitamin $\mathrm{B} 12$, on the $5^{\text {th }} \mathrm{d}$ of treatment both patients had tremors and myoclonus, and both responded to piracetam treatment within 1 week.

It is not clear how vitamin B12 deficiency causes neurological symptoms. Some studies have shown that congenital anomalies in homocysteine remethylation or an abnormality in the methionine synthetase reaction leads to neurological symptoms [3,15]. Grattan-Smith et al. [4] suggested that movement disorder in such cases is due to hyper activation of 
metabolic pathways that contain vitamin B12, and temporary vitamin B12 or folate metabolism imbalance. Changes in the plasma concentration of various amino acids were observed in response to vitamin B12 treatment. Although it has been proposed that hyperglycinemia is responsible for the involuntary movement observed in response to vitamin B12 treatment [7], it was also reported that glycine levels were normal [11].

It was reported that EEG results in patients with seizures due to vitamin B12 deficiency were abnormal, whereas normal EEG results were observed in patients with tremors and myoclonus $[1,12,13,16]$. As such, it was reported that use of antiepileptics was unnecessary and useless in patients with involuntary movements $[1,10,16]$. It is thought that involuntary movements is self-restricted and there is no consensus on the use of antiepileptic treatment $[7,10]$.

Cerebral atrophy and retarded myelination based on cranial MRI have been reported in many cases of infantile vitamin B12 deficiency [1,4,5,12-14,17]. Cranial MRI in the 2 presented cases showed atrophy in the frontoparietal cortex and interhemispheric region, and dilatation in the ventricles secondary to the observed atrophy. Data concerning the longterm prognosis of neurological symptoms due to vitamin B12 deficiency are inadequate. Although hematological symptoms varying from megaloblastic anemia to pancytopenia can be cured, neurological symptoms may persist $[4,16,18]$. Some studies reported no improvement in verbal or psychomotor ability despite vitamin B12 treatment, which suggests that neurological impairment may be irreversible if the diagnosis is delayed beyond 12 months [18,19]. Monagle et al. [19] reported that 2 of 6 patients with vitamin B12 deficiency were followed-up for long-term neurological sequelae, and von Schenk et al. [2] reviewed 25 patients with vitamin B12 deficiency reported in the literature and observed that 6 of the patients diagnosed at a mean age of 10 months had normal development at follow-up, while 6 others diagnosed at a mean age of 13 months had persistent developmental delay. In a study performed in the southeastern region of Turkey, psychomotor retardation was observed in all 33 patients with nutritional vitamin B12 deficiency. Eleven patients have been followed. Whereas the repeated developmental screening test results were normal in 6 patients who diagnosed $<18$ months, psychomotor retardation was persistent in 5 patients who diagnosed $>18$ months were continued the follow-up. [18]. Neurological development in a patient reported by Avci et al. [14] was near normal following vitamin B12 treatment, whereas in the 2 presented cases neurological development was normal.

C3, IgG, and IgM levels were low in mice with vitamin B12 deficiency [20]. Avci et al. [14] reported a patient with IgG and IgM deficiency that recovered following vitamin B12 treatment. Case 1, who presented due to frequently recurrent infections, had low IgG and IgA levels, and an IgM level at the lower limit of normal, whereas case 2 had low-level IgM. A clear decision could not be made whether low Ig levels are related to vitamin B12 deficiency or transient hypogammaglobulinemia of infancy. In our case, serum Ig levels normalized after vitamin B12 treatment, so within it was related with vitamin B12 deficiency.

In conclusion, children born with an insufficient vitamin B12 reserve can have vitamin B12 deficiency and such patients present with various clinical findings. Early diagnosis can prevent the occurrence of irreversible neurological damage in such patients.

\section{Conflict of interest statement}

The authors of this paper have no conflicts of interest, including specific financial interests, relationships, and/or affiliations relevant to the subject matter or materials included.

\section{References}

1. Casella EB, Valente M, de Navarro JM, Kok F. Vitamin B12 deficiency in infancy as a cause of developmental regression. Brain Dev 2005;27:592-4. [CrossRef]

2. von Schenck U, der-Gotze C, Koletzko B. Persistence of neurological damage induced by dietary vitamin B-12 deficiency in infancy. Arch Dis Child 1997;77:137-9. [CrossRef]

3. Dror DK, Allen LH. Effect of vitamin B12 deficiency on neurodevelopment in infants: current knowledge and possible mechanisms. Nutr Rev 2008;66:250-5. [CrossRef]

4. Grattan-Smith PJ, Wilcken B, Procopis PG, Wise GA. The neurological syndrome of infantile cobalamin deficiency: developmental regression and involuntary movements. Mov Disord 1997;12:39-46. [CrossRef] 
5. Rasmussen SA, Fernhoff PM, Scanlon KS. Vitamin B12 deficiency in children and adolescents. J Pediatr 2001;1381:10-7. [CrossRef]

6. Vry MS, Haerter K, Kastrup O, Gizewski E, Frings M, Maschke M. Vitamine-B12-deficiency causing isolated and partially reversible leukoencephalopathy. J Neurol 2005;252:980-2. [CrossRef]

7. Emery ES, Homans AC, Colletti RB. Vitamin B12 deficiency: a cause of abnormal movements in infants. Pediatrics 1997;99:255-6. [CrossRef]

8. Graham SM, Arvela OM, Wise GA. Long-term neurologic consequences of nutritional vitamin B12 deficiency in infants. J Pediatr 1992;121:710-4. [CrossRef]

9. Jadhav M, Webb JK, Vaishnava S, Baker SJ. Vitamin B12 deficiency in Indian infants. A clinical syndrome. Lancet 1962;2:903-7. [CrossRef]

10. Grech V, Vella C, Mercieca V. Temporary myoclonus with treatment of congenital transcobalamin 2 deficiency. Pediatr Neurol 2001;24:75-6. [CrossRef]

11. Chandra J, Jain V, Narayan S, Sharma S, Singh V, Batra $\mathrm{S}$, Dutta AK. Tremors and thrombocytosis during treatment of megaloblastic anaemia. Ann Trop Paediatr 2006;26:101-5. [CrossRef]

12. Ozer EA, Turker M, Bakiler AR, Yaprak I, Ozturk C. Involuntary movements in infantile cobalamin deficiency appearing after treatment. Pediatr Neurol 2001;25:81-3. [CrossRef]

13. Ozdemir O, Baytan B, Gunes AM, Okan M. Involuntary movements during vitamin B12 treatment. J Child Neurol 2010;25:227-30. [CrossRef]
14. Avci Z, Turul T, Aysun S, Ünal I. Involuntary movements and magnetic resonance imaging findings in infantile cobalamine (vitamin B12) deficiency. Pediatrics. 2003;112:684-6. [CrossRef]

15. Hall CA. Function of vitamin B12 in the central nervous system as revealed by congenital defects. Am J Hematol 1990;34:121-7. [CrossRef]

16. Benbir G, Uysal S, Saltik S, Zeybek Aktuglu C, Aydin A, Dervent A, Yalcinkaya C. Seizures during treatment of Vitamin B12 deficiency. Seizure 2007;16:69-73. [CrossRef]

17. Smolka V, Bekarek V, Hlidkova E, Hlídková E, Bucil J, Mayerová D, Skopková Z, Adam T, Hrubá E, Kozich V, Buriánková L, Saligová J, Buncová M, Zeman J. Metabolic complications and neurologic manifestations of vitamin B12 deficiency in children of vegetarian mothers. Cas Lek Cesk 2001;140:732-5.

18. Katar S, Nuri OM, Yaramis A, Ecer S. Nutritional megaloblastic anemia in young Turkish children is associated with vitamin B-12 deficiency and psychomotor retardation. J Pediatr Hematol Oncol 2006;28:559-62. [CrossRef]

19. Monagle PT, Tauro GP. Infantile megaloblastosis secondary to maternal vitamin B12 deficiency. Clin Lab Haematol 1997;19:23-5. [CrossRef]

20. Funada U, Wada M, Kawata T, Mori K, Tamai H, Isshiki T, Onoda J, Tanaka N, Tadokoro T, Maekawa A. Vitamin B-12-deficiency affects immunoglobulin production and cytokine levels in mice. Int J Vitam Nutr Res 2001;71:60-5. [CrossRef] 